\title{
DIAGNOSIS AND CONTROL OF THE DEVELOPMENT OF HEPATIC STEATOSIS IN DAIRY COWS IN THE POSTPARTURIENT PERIOD
}

\author{
A. PECHOVÁ ${ }^{1,}$, J. ILLEK $^{1}$, R. HALOUZKA ${ }^{2)}$ \\ ${ }^{1)}$ Clinic of Ruminant Diseases, 2'Department of Pathological Morphology, University of Veterinary and \\ Pharmaceutical Sciences, Brno, Czech Republic
}

Received June 17, 1997

Accepted January 15, 1998

\begin{abstract}
Pechová A., J. Illek, R. Halouzka: Diagnosis and Control of the Development of Hepatic Steatosis in Dairy Cows in the Postparturient Period. Acta vet. Brno 1997, 66:235-243.

The objective of the present investigations was to help the early diagnosis of hepatic steatosis. The experiment was carried out in 10 dry dairy cows in very good nutritional condition. The feed ration was restricted in the 2 nd week after parturition. On the 4 th day of this restriction hepatic biopsy was performed and according to the results the dairy cows were divided into group $\mathrm{S}$ ( 7 cows), i.e. those suffering from various stages of hepatic steatosis, and group $\mathrm{N}$ ( 3 cows), i.e. those with no increased deposition of fat in the liver. Blood and urea for laboratory examinations were sampled in the last week prior to parturition, in the 1 st week after parturition. in the 2 nd week after parturition (on the day of hepatic biopsy) and in the 4th week after parturition. The group of cows suffering from hepatic steatosis showed higher concentrations of FFA as compared with controls $\left(0.598 \pm 0.319\right.$ vs. $\left.0.229 \pm 0.017 \mathrm{mmol}^{-1}\right)$, total bilirubin $(6.230 \pm 2.97$ vs. $4.030 \pm 1.24$ $\mu$ mol. $\left.1^{-1}\right)$, AST $\left(1.82 \pm 0.528\right.$ vs. $1.21 \pm 0.195 \mu$ kat. $\left.1^{-1}\right)$, LD $(28.76 \pm 7.14$ vs. $20.81 \pm 1.84$ $\mu$ kat. $\left.1^{-1}\right)$, oxidized ketone bodies $\left(0.346 \pm 0.280\right.$ vs. $\left.0.176 \pm 0.015 \mathrm{mmol}^{-1} \mathrm{1}^{-1}\right)$, gamma-globulins $\left(34.57 \pm 12.36\right.$ vs. $\left.29.52 \pm 12.27 \mathrm{~g} .1^{-1}\right)$ as well as a higher $\mathrm{O} / \mathrm{T}$ ratio $(33.98 \pm 25.8$ vs. 13.84 $\pm 5.85 \%)$. On the other hand, the concentration of triacylglycerids $(0.027 \pm 0.014$ vs. $0.113 \pm 0.09$ mmol. $\left.1^{-1}\right)$ and the A/G ratio $(0.597 \pm 0.192$ vs. $0.691 \pm 0.166)$ were lower. Based on our investigations, the following indices appeared to be suitable for the diagnosis of hepatic steatosis: increased AST above $1.4 \mu \mathrm{kat} .1^{1}$. increased LD activity above $29 \mu \mathrm{kat} .1^{1-1}$, increased level of total bilirubin above $5.2 \mu \mathrm{mol} \cdot \mathrm{l}^{-1}$. increased level of oxidized ketone bodies in the blood plasma above $0.2 \mathrm{mmol} . \mathrm{1}^{-1}$. We recommend to check the respective indicators of lipid metabolism (FFA. total cholesterol, triacylglycerols) using diagnostic criteria given in the present paper.
\end{abstract}

Dairy cows, hepatic steatosis, blood plasma, metabolic profile

According to findings from slaughterhouses, incidence of hepatopathies in cattle is continuously increasing. The most frequent form of hepatopathy in cows is hepatic steatosis which appears most frequently during puerperium. In this period it has a negative effect not only on reproduction of the dairy cows but also on milk composition (Illek et al. 1995).

Clinical methods suitable to study hepatic steatosis are limited because they cannot be successfully applied until in an advanced stage of the disease. For diagnosis of the onset and subclinical hepatic diseases it is necessary to employ laboratory methods. The most reliable method for the detection of hepatic steatosis is considered to be the examination of hepatic tissue by biopsy (Johansen et al. 1990). Many indicators of the metabolic profile are recommended for diagnosis of the fat mobilization syndrome, but main attention is devoted to examination of the functional activity of the liver and to energy metabolism. Changes in energy metabolism are reflected, in particular, in increased FFA concentrations, decreased glycaemia. occurrence of hyperketonemia and hyperketonuria, decrease in concentrations of triacylglycerols and total blood cholesterol (Reichel 1989; Fürll et al. 1990; Rossow et al. 1991; Pechová and Illek 1996). As indicators of the condition of liver many authors recommend to check bilirubin (Staufenbiel 1990) and bile acid concentrations (Karsai and Szanis ló 1990). Also enzyme diagnosis is closely observed. Enzymes of the 
highest diagnostic value for hepatic diseases of cattle are considered to be AST, GMT and SD, the most frequently observed other enzymes are ALT, GLD, GMT, LD, OCT, AG and ALP (Kursa et al. 1988; Reichel 1989; Rossow and Staufenbiel 1990; Pechová 1992).

Individual authors often differ in their conclusions of the diagnostic value of the respective indicators of the biochemical profile and they are looking for indicators of early impairment of the hepatic tissue which would enable a timely therapeutical intervention.

\section{Materials and Methods}

Ten dry dairy cows in very good nutritional condition were included in the experiment. The feed ration was restricted in the 2 nd week after parturition when the dairy cows were fed only roughage (hay, maize silage, sugarbeet top silage, barley straw) without any concentrate for 3 days. On the 4 th day of this restriction hepatic biopsy was performed and according to its results the dairy cows were divided into group $S$ ( 7 cows), i.e. cows suffering from various stages of hepatic steatosis, and group $\mathrm{N}$ ( 3 cows), i.e. those with no increased deposition of fat in the liver. This model was chosen because it seemed to be the closest to natural conditions. Blood and urea for laboratory examinations were sampled in the last week prior to parturition. in the 1 st week after parturition, in the $2 \mathrm{nd}$ week after parturition (on the day of hepatic biopsy) and in the 4th week after parturition.

Blood was analysed on the automatic analyser COBAS MIRA using standard methods. Enzymes were determined using the following methods: ALT (M a lý et al. 1989a), AST (M a lý et al. 1989b). ALP (C h r o m ý et al. 1989), GMT ( $\mathrm{Zahradníce} \mathrm{k} \mathrm{et} \mathrm{al.1986),} \mathrm{LD} \mathrm{(H} \mathrm{a} \mathrm{j} \mathrm{ze} \mathrm{r} \mathrm{and} \mathrm{Ja} \mathrm{ge} \mathrm{l} \mathrm{k} \mathrm{o} \mathrm{vá} \mathrm{1988).} \mathrm{FFA} \mathrm{was} \mathrm{determined}$ photometrically (D i e te rle et al. 1968), the individual protein fractions by electrophoresis on acetylcellulose foil and ketone bodies by gas chromatography ( $\mathrm{H} \mathrm{rade} \mathrm{c} \mathrm{k} \mathrm{ý} \mathrm{et} \mathrm{al.} \mathrm{1972).}$

The bioptates of hepatic tissue were elaborated using a freezing technique and stained with oil red to detect neutral fats. Their morphological evaluation was carried out at the Department of Pathological Morphology using a semiquantitative method:

+steatosis affecting the perilobular zones of lobules of the terminal hepatic vein of 1-4 hepatocytes in the hepatic trabecular

${ }^{++}$steatosis affecting the perilobular zones of lobules of the terminal hepatic vein of $1 / 3$ of the hepatic trabecular with simultaneously occurring hyperplasia of RHS

${ }^{+++}$steatosis affecting the perilobular zones of lobules of the terminal hepatic vein of $1 / 2$ of the hepatic trabecular with centrilobular necroses of hepatocytes. fibroproduction of the portobiliar stroma and its cellulisation with singular eosinophiles, lymphocytes and histiocytes, sporadically with mild cholestasis.

Diffusion steatosis - affecting the hepatic parenchyma without predilection and with the occurrence of lipid globules of various sizes in hepatocytes and with mesenchymal reaction.

The resuits were evaluated using the Statgraphics program, Student's t-test was used for assessment of differences.

\section{Results and Discussion}

The development of hepatic steatosis was studied in the postparturient period of dairy cows in very good nutritional condition. Based on liver biopsy the dairy cows were divided into two goups. Group $\mathrm{N}$ included three dairy cows in which histological examinations revealed lipid globules in hepatocytes. Group $\mathrm{S}$ included 7 dairy cows with an increased level of lipid in hepatocytes ( 2 dairy cows,+ 2 dairy cows,++ 3 dairy cows +++ ).

Figs 1-20 show the results of selected clinico-biochemical indices. The fat mobilisation syndrome was found to develop in the dairy cows under study as early as the 1st week post partum, in the 2 nd week their feed ration was restricted for 3 days, i.e. the animals were given no concentrates in order to emphasize this syndrome. In the development of fat mobilisation there was a high variability in responses to the same exogenous conditions.

Since fat mobilisation is primarily a physiological mechanism, it is very difficult to determine the moment when it becomes a pathological process. That is why we studied the differences between both groups. These differences were not statistically significant due, on 
the one hand, to a small number of animals in the groups, but also due to different extent of hepatic steatosis in the individual dairy cows of group $\mathrm{S}$.

In both groups the decrease in plasma glucose concentration (Fig. 1) was the same, and there was no distinct relation between the level of liver impairment and plasma glucose concentration. Neither Reichel (1989) was able to find such direct relationship between the plasma glucose and hepatic steatosis.

The concentration of ketone bodies is considered to be a reliable indicator of the energy balance (Fürll et al. 1990). Total and oxidised ketone bodies are given in Figs 2 and 3 . In our experiment we found increased concentrations of ketone bodies in the blood plasma of both groups of dairy cows. The highest concentration (i.e. 2.194 mmol. $1^{-1}$ ) was found in the 2 nd week p.p. in dairy cows with no hepatic steatosis, while in dairy cows with hepatic steatosis it ranged from 0.716 to $1.798 \mathrm{mmol}^{-1}$. The relations between the lipid content in liver and concentration of oxidised ketone bodies in the blood plasma were closer even though the differences in average values were not significant. The ratio between oxidised and total ketone bodies $(\mathrm{O} / \mathrm{T})$ in blood plasma (Fig. 4) did not clearly confirm the relationship to hepatic steatosis. In spite of the fact that the average values of $0 / T$ were higher in group $\mathrm{S}$ than in group $\mathrm{N}$ during the entire experiment, these differences were not significant and within the groups there were great differences only between the individual dairy cows.

Indicators of lipid metabolism (triacylglycerols - TAG, total cholesterol - TCH, free fatty acids - FFA), given in Figs. 5-7, are important for the diagnosis of hepatic steatosis.
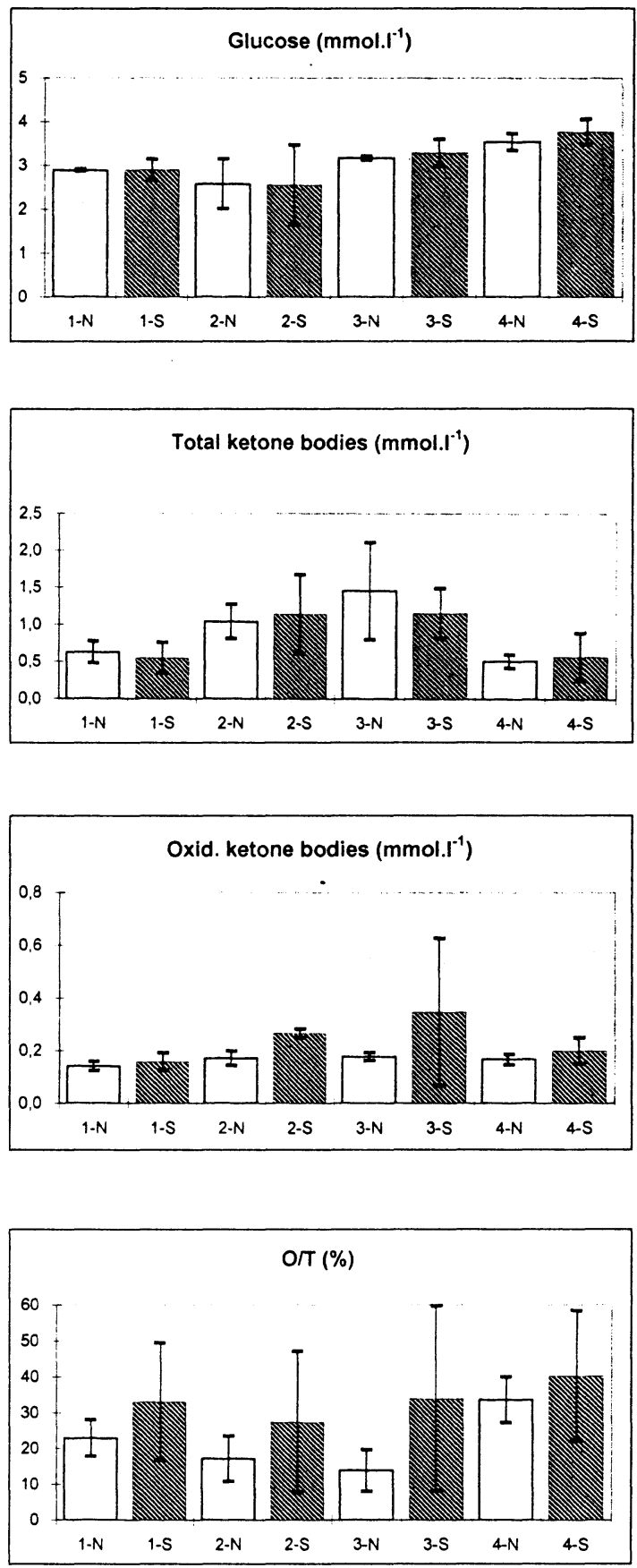

Fig. 1.-4. Biochemical indices in control (N) and steatosis (S) groups of cows. Numbers $1-4$ indicate blood samplings 1-4. 
Evaluations of average values did not reveal any significant differences in these indicators between the two groups. The highest were differences in FFA. Compared with values given by Holtenius (1989) for cows suffering from hepatic steatosis. i.e. $1.26 \pm 0.43 \mu \mathrm{mol}^{1.1} \mathrm{1}^{-1}$ our average values are relatively low. Fat mobilisation and an increase in FFA concentrations occurred in the 1 st week p.p. in all the dairy cows and in the 2 nd week p.p. the FFA values dropped in cows with no hepatic steatosis or with only a mild one. Increased FFA concentrations in the group of cows with fatty liver lasted during the entire postparturient period reaching the highest levels in the 4th week. Based on recommendations of Reichel (1989) we consider values of $0.350 \mu$ mol. $1^{-1}$ of plasma FFA to be above the physiological limit. Mazir et al. (1988) found correlation coefficients among triacylglyceroles in the liver and FFA in the blood plasma of $r=$ 0.64 but their opinion is that in spite of the observed correlations the FFA concentration is not a reliable indicator for diagnosis of hepatic steatosis. The FFA level is, in particular, a criterion of fat mobilisation and reflects the condition of the hepatic parenchyma only indirectly.

The plasma triacylglycerol concentration is important for diagnosis of hepatic steatosis; the reduction of TAG below $0.17 \mathrm{mmol}^{-1}$ is considered to be pathognomic (Reichel 1989). In our experiment we found very low TAG values in the 1 st and 2 nd weeks p.p. in both groups. On the basis of our results we consider TAG to be an auxiliary indicator for the diagnosis of hepatic steatosis because the differences between the two groups were very small.
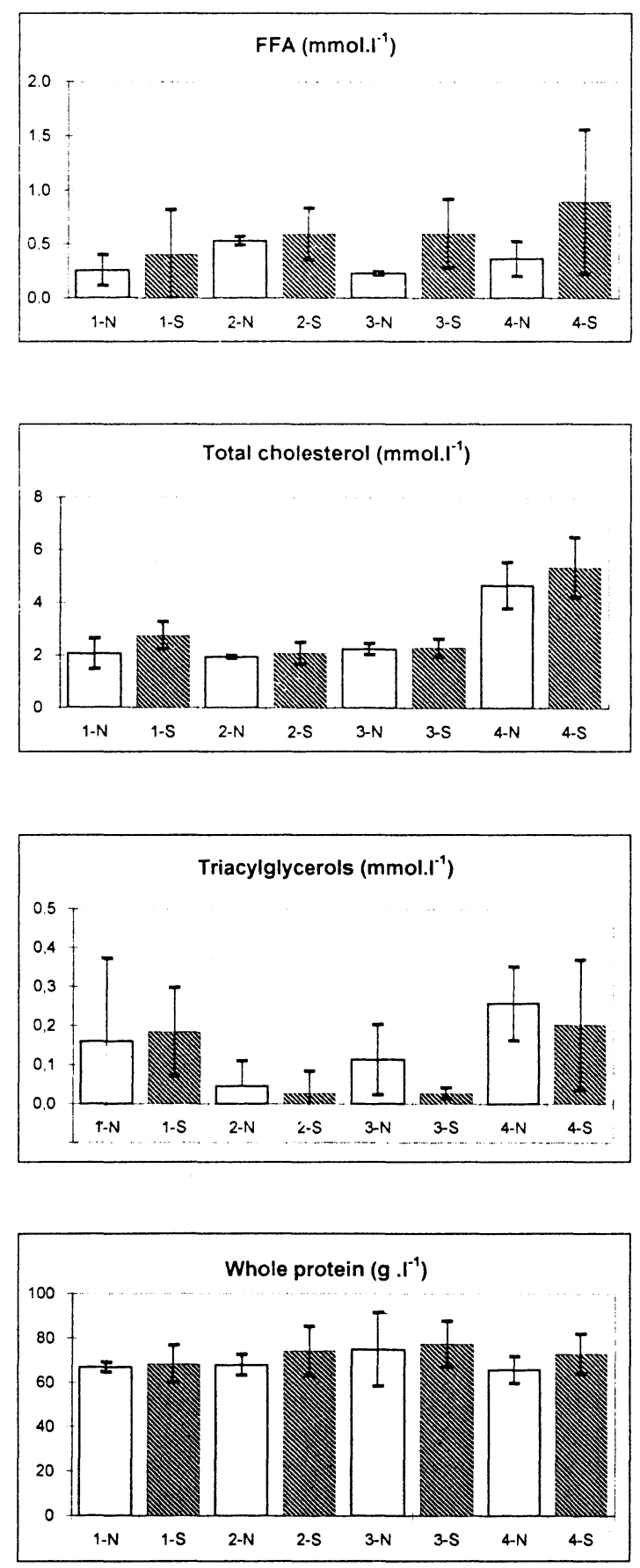

Fig. 5.-8. Biochemical indices in control $(\mathrm{N})$ and steatosis $(\mathrm{S})$ groups of cows. Numbers $1-4$ indicate blood samplings $1-4$. 
The total plasma cholesterol concentration did not correlate with the level of lipids in liver and decreased below $2.6 \mathrm{mmol}^{\mathrm{1}^{-1}}$ (Reichel 1989) in the 1st and 2nd weeks p.p. in both groups. On the contrary, Holtenius and Hjört (1988) found great differences in the cholesterol level between healthy cow's and cows with fatty liver. Also Mostaghni and Askari (1996) reported reduced cholesterol levels in the first month after parturition in dairy cow's given restricted feed rations.

Diagnostic values of FFA, triacylglyceroles, and total cholesterol were limited to a certain extent evidently also due to variations of values in the course of the day. Bitman et al. (1989) found the following amplitudes (expressed in per cent of the average values): FFA - $68.2 \%$, triacylglyceroles - 55.8\%, cholesterol ester $19.2 \%$ and free cholesterol - $17.5 \%$.

As the diagnosis of hepatic steatosis poses a serious problem and the diagnostic value of the individual clinical and biochemical indices rather limited, some authors recommend the following diagnostic criteria:

Haraszti et al. (1982) FFA/TG ratio $>4$ - positive

$<2$ - negative

\section{Holtenius (1990) FFA/TCH ratio}

$<0.2$ - negative

Reid et al. (1983)

$y=-0.51-3.2 . F F A+2.84$.glucose -3.168 .AST

$y<0$ - positive

$y>1.5$ - negative

Reichel (1989)

$y=-0.51-3.2 . F F A+2.85 . T C H-3.168$.AST

$\mathrm{y}<0$ - positive

$y>1.5$ - negative

Tab. 1 (see p. 242) gives comparisons of the given diagnostic criteria with biopsy of liver.
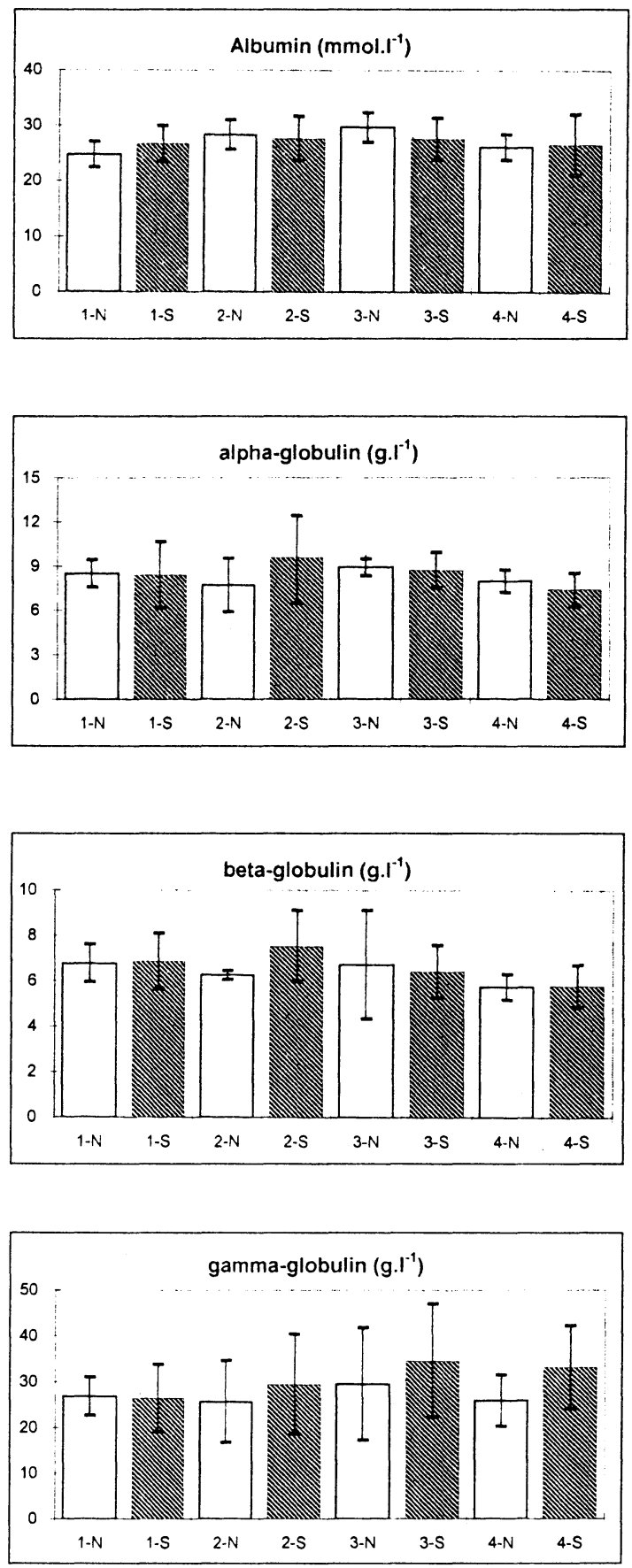

Fig. 9.-12. Biochemical indices in control $(\mathrm{N})$ and steatosis $(\mathrm{S})$ groups of cows. Numbers $1-4$ indicate blood samplings $1-4$. 
Many authors prefer to measure enzyme activities and consider them to be more sensitive and specific. In our experiment we determined the catalytic activities of AST, ALT, GMT, ALP and LD (Figs. 16 - 20). Only AST and LD showed a closer relationship to hepatic steatosis.

According to our results the activity of plasma aspartate aminotransferase (AST) yields the best evidence of the deposition of fat in liver. In all samples the average AST activities were higher in group $\mathrm{S}$ than in group $\mathrm{N}$ even though the differences were not significant. On the basis of individual evaluations of the respective animals we consider the activity of AST of $1.3 \mu \mathrm{kat} .1^{-1}$ as the limit that may be found in animals not suffering from hepatic steatosis but, at the same time, also in dairy cows with mild hepatic steatosis. When the lipid amount in liver was higher, also the AST catalytic activity increased to $1.5-2.7 \mu \mathrm{kat} .1^{-1}$. Also the values of $0.72-1.41 \mu \mathrm{kat} .1^{-1}$ found in healthy dairy cows correspond with these results (Pechová 1992). Schäfer et al. (1990) found similar AST activities; with a $10 \%$ level of fat in liver they give values of $1.12-1.17$ $\mu$ kat. $1^{-1}$, with $10-15 \%$ of fat 1.36 $\mu$ kat..$^{-1}$ and when the fat level is higher than $15 \%$, AST catalytic activity amounts to $2.043 \mu \mathrm{kat} .1^{-1}$.

Lactate dehydrogenase (LD) is another enzyme that has been repeatedly studied in association with hepatic steatosis. In our study, the activity of LD increased rapidly after parturition, and was higher in group S during the 1 st and 2 nd postparturient weeks. It corresponded well with the degree of hepatic steatosis. The values for severe steatosis were $38.33-34.19$ - $30.55 \mu$ kat. $1^{-1}$, in the $\mathrm{N}$ group they were $21.43-22.27-18.74 \mu \mathrm{kat} .1^{-1}$. Uhlig et al. (1988) proved
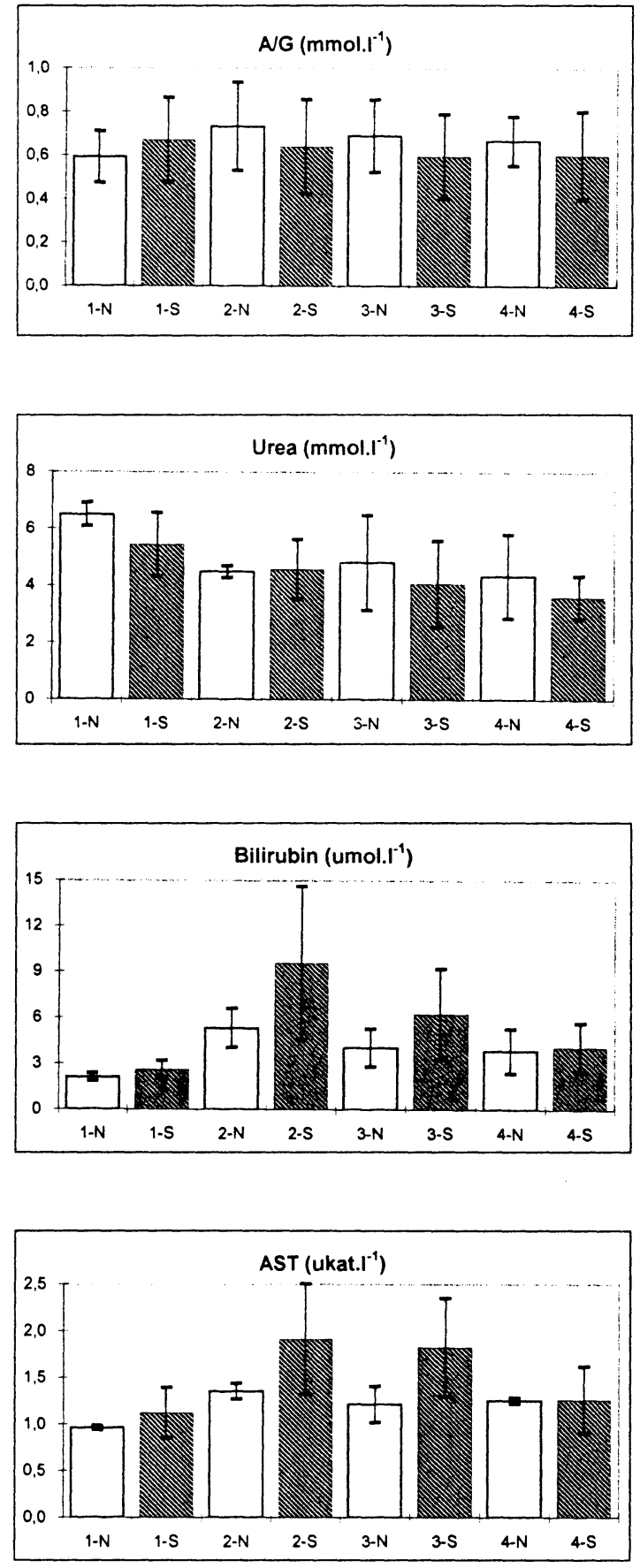

Fig. 13.-16. Biochemical indices in control $(\mathrm{N})$ and steatosis $(\mathrm{S})$ groups of cows. Numbers $1-4$ indicate blood samplings $1-4$. 
a relationship between the level of fat in liver and the activity of LD. The concentration of total plasma bilirubin (Fig. 15) was higher in group $\mathrm{S}$ than in group $\mathrm{N}$ all the time and in the lst and 2nd weeks p.p. it exceeded the physiological limit, i.e. $5.13 \mu \mathrm{mol} .1^{-1}$.

Albumins and globulins are also indicators of the functional condition of the hepatic parenchyma (Figs 9-13). Serum albumin concentration was lower than 30 g. $1^{-1}$ in both groups during the entire experiment. Due to the great variability in both groups we do not consider the level of plasma albumin to be a reliable indicator of hepatic steatosis. The levels of alfa and beta-globulins were similar in both groups. Greater changes were found in serum gamma-globulin concentrations; in group $S$ they were higher after parturition when also the values of the A/G coefficient were lower in group $\mathrm{S}$ than in group $\mathrm{N}$ in which they ranged in the lower limit of the reference range, i.e. 0.73-1.03 (Slanina et al. 1985). However, differences among the animals were also great. According to our results, electrophoresis of proteins is not a reliable method for the diagnosis of hepatic steatosis.

\section{Diagnostika a sledování rozvoje steatózy jater \\ u dojnic v poporodním období}

Cílem tohoto sledování bylo přispět k objasnění časné diagnostiky jaterní steatózy. Do pokusu bylo vybráno 10 dojnic ve velmi dobrém výživném stavu v období zaprahnutí. Ve 2.týdnu po porodu byla provedena restrikce krmné dávky. Čtvrtý den po zahájení restrikce krmné dávky byla provedena biopsie jater a podle jejího výsledku byly dojnice rozděleny na skupinu $S$ (7 ks) s různým stupněm steatózy jater a na skupinu $\mathrm{N}$ ( $3 \mathrm{ks}$ ) bez zvýšeného ukládání tuku v játrech. Odběry krve
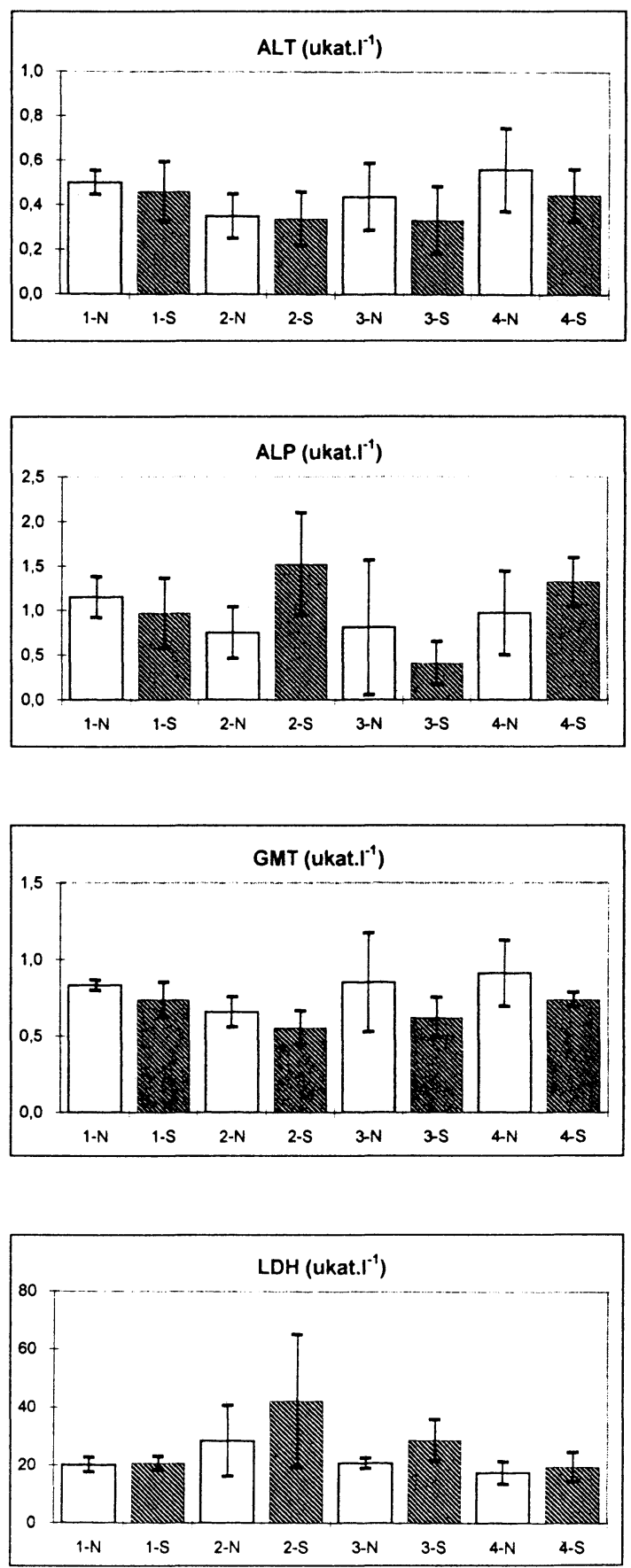

Fig. 17.-20. Biochemical indices in control $(\mathrm{N})$ and steatosis $(\mathrm{S})$ groups of cows. Numbers $1-4$ indicate blood samplings $1-4$. 
a moče pro laboratorní vyšetření byly provedeny $v$ posledním týdnu před porodem, $v 1$. týdnu po porodu, ve 2. týdnu po porodu ( $v$ den biopsie jater) a ve 4 . týdnu po porodu. U skupiny krav se steatózou jater byly ve srovnání s kontrolami zjištěny vyšší koncentrace $\operatorname{NEMK}\left(0,598 \pm 0,319\right.$ versus $\left.0.229 \pm 0,017 \mathrm{mmol}^{-1} \mathrm{l}^{-1}\right)$, celkového bilirubinu $(6,230 \pm 2.97$ vs. $\left.4,030 \pm 1,24 \mu \mathrm{mol}^{-1}\right)$, AST ( $1.82 \pm 0,528$ vs. $\left.1,21 \pm 0,195 \mu \mathrm{kat}^{-1} \mathrm{l}^{-1}\right)$, LD $(28,76 \pm 7.14$ vs. $\left.20,81 \pm 1,84 \mu \mathrm{kat}^{-1} \mathrm{l}^{-1}\right)$, oxidovaných ketolátek $\left(0,346 \pm 0.280\right.$ vs. $\left.0,176 \pm 0,015 \mathrm{mmol} . \mathrm{l}^{-1}\right)$,

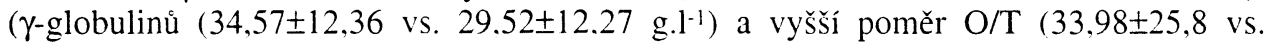
$13,84 \pm 5,84 \%)$. Naopak nižší byla koncentrace triacylglycerolů $(0,027 \pm 0,014$ vs. $\left.0,113 \pm 0,09 \mathrm{mmol} . \mathrm{l}^{-1}\right)$ a hodnoty $\mathrm{A} / \mathrm{G}$ poměru $(0,597 \pm 0,192$ vs. $0.691 \pm 0.166)$. Na základě našeho sledování se pro diagnostiku steatózy jater jeví jako vhodné následující parametry:

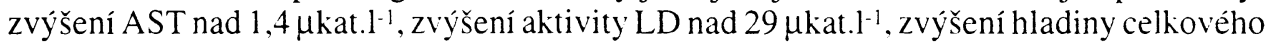
bilirubinu nad 5,2 $\mu \mathrm{mol}^{-1}{ }^{-1}$. zvýšení hladiny oxidovaných ketolátek v krevní plazmě nad $0,2 \mathrm{mmol}^{-1}{ }^{-1}$ Jednotlivé ukazatele lipidového metabolismu (NEMK, celkový cholesterol, triacylglyceroly) doporučujeme sledovat pomocí diagnostických kritérií uvedených $\mathrm{v}$ článku.

Table 1

Comparison of diagnostic indices in blood plasma and liver biopsy

\begin{tabular}{|l|c|c|c|c|c|c|}
\hline \multicolumn{1}{|l|}{ Index } & FFA/TG & FFA/TCH & Reid (83) & Reichel (89) & Biopsy \\
\hline No liver steatosis & $\mathbf{1}$ & 2.05 & 0.115 & 3.78 & 0.68 & - \\
& $\mathbf{2}$ & 1.14 & 0.108 & 5.15 & 1.59 & - \\
& $\mathbf{3}$ & 7.1 & 0.086 & 2.79 & 1.63 & - \\
\hline Liver steatosis & $\mathbf{1}$ & 83.8 & 0.376 & -0.49 & $-3.36 \cdot$ & + \\
& $\mathbf{2}$ & 18.3 & 0.156 & 4.4 & 0.73 & + \\
& $\mathbf{3}$ & 7.5 & 0.113 & 3.57 & -0.77 & ++ \\
& $\mathbf{4}$ & 18.85 & 0.131 & 3.04 & 2.18 & ++ \\
& $\mathbf{5}$ & 25.38 & 0.387 & -4.8 & -4.97 & +++ \\
& $\mathbf{6}$ & 18.59 & 0.467 & -2.12 & -4.72 & +++ \\
& $\mathbf{7}$ & 21.75 & 0.214 & 2.8 & -0.52 & +++ \\
\hline Agreement (\%) & & $\mathbf{9 0}$ & $\mathbf{6 0}$ & $\mathbf{6 0}$ & $\mathbf{7 0}$ & $\mathbf{1 0 0}$ \\
with biopsy results & & & & & & \\
\hline
\end{tabular}

\section{References}

BITMAN. J., l'OOD, D. L., LEFCOLRT, A. M. 1990: Rhythms in cholesterol, cholesterol esters, free fatty acids. and triglycerides in blood of lactating dairy cows. J. Dairy Sci. 73: 948-955

DIETERLE, P.. HELDRICK, C. W., HANNER. J., SCHWARTZ. K. 1968: Non-esterified fatty acids, Biochemical Boehringer Test. Klin. Chem a Klin. Biochem. 6: 153-155

FÜRLL, M., WEHLITZ, A., SCHÄFFER, M. 1990: Lipolyse und Ketogenese bei Milchkühen mit permanenter Unterversorgung. In: Symposium Energie- und Fettstoffwechsel der Milchkuh, Berlin, pp. 266-272

HARASZTI, J., HUSZENICA, G. Y., MOLNÁR, L., IVANITS, J., FEKETE, J. 1982:Viszgálatok szárazonalló ,.elhízot" tehenek ellés utáni nemi mukodésével kapcsolatban.I Klinikai vizsgálatok. Magy. Ao.Lapja 37: 199 204

HRADECKÝ. P., JAGOŠ, P., JANÁK, J. 1978: Gas chromatographic head-space analysis of clinically interesting ketone bodies. J. Chrom. 146: 327-332

HOLTENIUS. P.1989: Plasma lipids is normal cows around partus and in cows with metabolic disorders with and without fatty liver. Acta Veter. Scand. 30: 441-445

HOLTENIUS. P., HJÖRT, M. 1988: Studies on the pathogenesis of fatty liver in cows. In: Proc. XVth World buiatric congress, Palma Mallorca, pp. 214-220

HOLTENIUS. P.1990:Disturbances in the regulation of energy metabolism around parturition in cows. In: Symposium Energie- und Fettstoffwechsel der Milchkuh, Berlin, pp. 226-232

CHROMÝ, V.. ZAHRADNIĆEK, L., VOZNÍCEKK, J. 1989: Návrh standardizované metody pro stanovení katalytické koncentrace alkalické fosfatázy v séru. Biochem. Clin. Bohemoslov. 18: 57-68 
ILLEK. J., PECHOVÁ. A.. SUCHÝ. P. 1995: Effect of Liver steatosis on the composition of cow milk. In: Proc. IXth International Conference on Production Diseases in Farm Animals, Berlin, p.160

JOHANNSEN. U., FÜRLL, M.. SCHÄFFER, M. F.. EHRENTRAUT, W., DECKERT, W., GEINITZ, D. 1990: Untersuchungenzum Lipidgehalt der Leber von Kühen in Abhängigkeit vom Laktationsstadium. In: Sympozium Energie- und Fettstoffwechsel der Milchkuh, Berlin, pp. 319-326

KARSAI. F., SZANISLÓ, F. 1990: Changes in the serum levels of primary bile acids in dairy cows. Acta Veter. Acad. Sci. Hung. 38: 217-224

KURSA. J., KROUPOVÁ. V.. KLEIN, Z., ČOLÁK. D., KRATOCHVÍL, P. 1988: Metabolické poruchy a hepatopatie u dojnic. Sb. VŠZZ Agr. Fak.. C. Budějovice, Ř. Zootech., pp. 79-117

MALÝ. M., ZAHRADNÍČEK, L., BALA. J. 1989: Návrh standardizované metody pro stanovení katalytické koncentzrace ALT v krevním séru. Biochem. Clin. Bohemoslov. 18: 39-50

MALÝ. M., ZAHRADNÍCEK. L., BALA. J. 1989: Návrh standardizované metody pro stanovení katalytické koncentzrace AST v krevním séru. Biochem. Clin. Bohemoslov. 18: 27-38

MAZUR. A., RAYSSIGUIER. Y., GUEUX. E., BAZIN. S. 1988: Importance de la steatose hepatique chez la vache laitiere presentant des troubles metaboliques en debout de lactation. In: Proc. XVth World Buiatric Congress, Palma Mallorca, pp.252-256

MOSTAGHNI, K., ASKARI, M. 1996: Changes in serum albumin, cholesterol and glucose concentrations in subclinical fatty liver syndrome in dairy cattle. J. Appl. Anim. Res. 10: 33-38

PECHOVÁ. A. 1992: Diagnostika a prevence lipomobilizačního syndromu u dojnic v poporodním období. PhD. Thesis. Univ. Vet. Pharm. Sci., Brno, p.170

PECHOVÁ, A.. ILLEK. J. 1996: Diagnostika steatózy jater a lipomobilizačního syndromu u skotu. Veterinářství 56: 528-530

QUALMANN. K.. REHAGE, J.. BEYERBACH, M., SCHOLZ, H. 1995: Hyperbilirubinemia in dairy cows with lipomobilisation syndrome and its relation to high serum concentrations of non esterified fatty acids.In: Proc. IX International Conference on Production Diseases in Farm Animals, Berlin. p. 50

REID. I. M., ROWLANDS. G. J., DEW, A. M., COLLINS, R. A., ROBERTS, C. J., MANSTON. R. 1983: The relatioship betwen post-parturient fatty liver and blood composition in dairy cows. J. agric. Sci., Camb. 101: 473-480

REICHEL. P. 1989: Etiopatogenéza syndrómu stučnenia kráv z hladiska diagnostiky, prevence a terapie. PhD. Thesis, Univ. Vet. Sci. Košice, p.156

ROSSOW. N., STAUFENBIEL, B. 1990: Kontrolle des Energie- und Fettstoffwechsels bei Hochleistungskühen. In: Sympozium Energie- und Fettstoffwechsel der Milchkuh, Berlin. pp.356-363

ROSSOW. N.. STAUFENBIEL. B., STAUFENBIEL. R., GÜRTLER, H.. DARGEL. D., NEUER, R. 1991: Zur Bewertung erhöhter Ketonkörperkonzentrationen bei der Milchkuh. Mh. Vet.-Med. 46: 11-17

SCHÄFER. M., FÜRLL, M., JOHANSEN, U., EHRENTRAUT, W., DECKERT, W., GEINITZ, D. 1990: Verhalten klinisch-chemischer Kennwerte des Blutes von Michkühen in Abbängigkeit vom Fettgehalt der Leber. In: Sympozium Energie- und Fettstoffwechsel der Milchkuh. Berlin. pp.301-308

SLANINA. L. et al. 1985: Klinická diagnostika vnútorných chorôb hospodárskych zvierat. 3.vyd., Bratislava, Príroda. $1985,493 \mathrm{p}$.

STAUFENBIEL. B. 1990: Experimentalle Untersuchungen zur Beurteilung der Energiebilanz der Milchkuh. In: Sympozium Energie- und Fettstoffwechsel der Milchkuh, Berlin, pp. 106-124

UHLIG, A., SCHÄFER, M., JOHANSEN, U. 1988: Untersuchungen zur Leberfunktion der Milchkühe im peripartalen Zeitraum. 2. Verhalten labordiagnosticher Kennwerte mit Beziehung zur Leberfunktion. Arch. Exp. Veter. Med. 42: 108 - 117

Address for correspondence:

MVDr. A. Pechová, CSc.

Clinic of Ruminat Diseases

Lniversity of Veterinary and Pharmaceutical Sciences

Palackého 1-3

61242 Brno

Czech Republic

Phone: 420541562408 